\title{
Modeling the Relationship Between Organizational Trust, Job Performance, Identity and Organizational Identification
}

\author{
Sabahattin TEKİNGÜNDÜZ iD a Emine KARABEL (iD b Aysu ZEKİOĞLU iD c Seçil Ömür SÜNBÜL iD d \\ a Mersin University, School of Health, Department of Health Care Management, Mersin, Turkey. stekingunduz@gmail.com \\ b emine.kiyak@saglik.gov.tr \\ c Trakya University, Faculty of Health Science, Department of Health Care Management, Edirne, Turkey. aysukurtuldu@trakya.edu.tr \\ d Mersin University, Department of Test and Assessment in Education, Faculty of Education, Mersin, Turkey. secilomur@mersin.edu.tr
}

\begin{tabular}{|c|c|}
\hline ARTICLE INFO & ABSTRACT \\
\hline $\begin{array}{l}\text { Keywords: } \\
\text { Organizational trust } \\
\text { Job performance } \\
\text { Identity } \\
\text { Organizational identification }\end{array}$ & $\begin{array}{l}\text { Purpose - Organizational trust and job performance are important variables for hospitals, } \\
\text { employees and patients. Numerous studies emphasize the critical role of organizational trust and } \\
\text { employee performance in enhancing organizational performance. The primary aim of the study is } \\
\text { to examine the effect of organizational identification and identity on organizational trust, and, as a } \\
\text { secondary aim, to investigate the effects of organizational trust, organizational identification and } \\
\text { identity on job performance }\end{array}$ \\
\hline $\begin{array}{l}\text { Received } 31 \text { January } 2020 \\
\text { Revised } 30 \text { April } 2020 \\
\text { Accepted } 4 \text { May } 2020\end{array}$ & $\begin{array}{l}\text { Design/methodology/approach - This cross-sectional study was carried out in three public health } \\
\text { institutions providing different types of services in a city in Turkey between } 02.02 .2017 \text { and } \\
02.03 .2017 \text {. The participants were } 649 \text { health professionals. Data were collected using a personal } \\
\text { information form, the organizational trust scale, the job performance scale, the Utrecht-Management } \\
\text { of Identity Commitments Scale (U-MICS), and the organizational identification scale. The correlation } \\
\text { coefficients between the variables were calculated. Determinants of organizational trust and job } \\
\text { performance were examined using Structural Equality Models (SEM). }\end{array}$ \\
\hline $\begin{array}{l}\text { Article Classification: } \\
\text { Research Article }\end{array}$ & $\begin{array}{l}\text { Findings - A path analysis was performed for the model established with SEM. Organizational } \\
\text { identification and identity variables were found to be significant predictors of organizational trust. } \\
\text { Also, organizational identification and identity were also important variables affecting job } \\
\text { performance. }\end{array}$ \\
\hline & $\begin{array}{l}\text { Discussion - The findings of the study reveal how important it is for the employee to identify with } \\
\text { the organization and to establish a permanent identity in the increase of trust level. A gradual } \\
\text { decrease in the feeling of satisfaction with existing commitment can adversely affect employee trust. } \\
\text { Higher perception of organizational identification and identity can have a positive impact on job } \\
\text { performance. }\end{array}$ \\
\hline
\end{tabular}

\section{Introduction}

One of the most important challenges for organizations is to adapt to different employees. Attitudes and behaviors of employees, who make up this workforce diversity, gain importance in reaching both individual and organizational goals.

The concept of trust is that a person believes that he or she will receive support and cooperation in solving problems at the time he or she needs it without any condition, and he or she feels a sense of trust and commitment without any perception of fear, hesitation and suspicion (Altuntas \& Baykal, 2010). Organizational trust is the belief that the individual or group will make every effort to ensure that individuals or organizations act in good faith with commitments, whether open or confidential, a result of honesty commitments in relationships, and not trying to benefit from others even if they have opportunities (Cummings \& Bromiley, 1996). Witteman (2015) reported positive correlational relationship between organizational trust and organizational culture dimensions. Mangles (2015) found significant and positive relationship between organizational trust and job satisfaction. Velez (2006 ) found significant and positive relationship between organizational trust and patient satisfaction.

The idea that behavioral responses such as job satisfaction and organizational commitment may be related to performance continues to attract the attention of academics as well as managers (Rodrigues \& Carlos 2010). Önerilen Atıf/Suggested Citation

Tekingündüz, S., Karabel, E., Zekioğlu, A., Sünbül, S.Ö. (2020). Modeling the Relationship Between Organizational Trust, Job Performance, Identity and Organizational Identification, Journal of Business Research-Turk, 12 (2), 1192-1206. 
Today's modern organizations focus on customer satisfaction, employee motivation, empowerment and personal responsibility in order to be able to efficiently survive in a turbulent economic environment, and they expect their employees to be proactive, to take initiative, and to cooperate and perform at high standards in performing their roles (Bakker \& Schaufeli, 2008; Chughtai \& Buckley, 2011; Karatepe \& Aga, 2016). In addition to being an important component affecting the quality perception of service buyers, employees' immediate performance of service interactions is also an important factor for continuing preference. Improved job performance also gives managers confidence in their subordinates due to success in the job. For this reason, organizations practice performance programs such as incentives, training and mentoring to increase the job performance of their employees (Aryee et al. 2002; Bitmiş \& Ergeneli, 2013; Viswesvaran \& Ones, 2000). Iaffaldano and Muchinsky (1985), Ceylan and Ulutürk (2006), Yousef (2000) Gül et al. (2008) reported positive relationship between performance and job satisfaction. Dirks and Ferrin (2002) found significant and positive relationship between performance and trust.

The process of identity formation, which becomes more prominent during the transition period to adolescence and adulthood, is critical throughout life (Crocetti et al. 2010). Macro factors such as culture, economy, demographic characteristics, politics, etc. and micro factors such as interpersonal communication, speech, written or routine daily interactions influence each other in identity development process (Adams \& Marshall, 1996). The work environment, social interactions, and interpersonal relations have an important role in this development. Professional identity develops with daily interaction in the work environment and the structure varies depending on occupational groups (Kanefuji \& Nakatani, 2017). For nurses as health professionals, socialization, role development and self-reflection are the premises of professional identity, and the increase in professional commitment and professional behaviors are considered as the results of professional identity (Sharbaugh, 2009).

Organizational identification is specific to the organization. In organizational identification, there is a perception of unity with the organization, necessarily reflecting one's self-perception. Organizational identification is about the question "How do I perceive myself about my organization? (Ashforth et al. 2008). While identity is the organization itself or the individual himself or herself, organizational identification can be defined as the "perception of sense of belonging to the group and consensus, or unity of the group in other words, by including the experiences of success or failure of the organization" (Ashforth \& Mael, 1989).

\section{Material and Methods}

\section{Research Model}

The primary aim of this study was to examine the effects of organizational identification and identity on organizational trust. The secondary aim was to examine the effects of organizational trust, organizational identification and identity on job performance. The reasons that make the study unique are the facts that the study was conducted in three public health institutions that provide different types of services in a city and that the organizational trust, job performance, organizational identification and identity variables were within the Structural Equation Model (SEM) at the same time.

\section{Study Group}

This cross-sectional study was conducted in three public hospitals in Bingöl, Turkey between 02.02.2017 and 02.03.2017. Demographic data are shown in Table 1. The study population consisted of 649 health professionals working in these three hospitals. No sample was taken in the study, and it was aimed to reach the entire population. The response rate of the scales by the population was $61 \%$ (Table 1 ).

Table 1. Distribution of health professionals by institutions

\begin{tabular}{|c|c|c|c|}
\hline Institution & $\begin{array}{c}\text { Active } \\
\text { employee }\end{array}$ & $\begin{array}{c}\text { Participation in } \\
\text { the study }\end{array}$ & Participation Percentage \\
\hline Oral and Dental Health Center & 40 & 40 & 100 \\
\hline Public Hospital & 406 & 214 & 53 \\
\hline Obstetrics and Pediatrics Hospital & 203 & 143 & 70 \\
\hline Total & 649 & 397 & 61 \\
\hline
\end{tabular}




\section{Data Collection Tools}

Data were collected using a personal information form, the organizational trust scale, the job performance scale, the U-MICS, and the organizational identification scale.

\section{Organizational Trust Scale}

Developed by Tyler and Bies (as cited in Polat, 2009), the organizational trust scale consists of four items. The response categories of the items in this scale are graded on a 5-point scale (1:Strongly Disagree, 5:Strongly Agree). The reliability and validity of the scale for use in Turkish were tested by Polat (2009). In the exploratory factor analysis in the study of Polat (2009), The Kaiser-Meyer-Olkin (KMO) Measure of Sampling Adequacy value was determined as $0.845(\mathrm{p}<0.001)$ and the items converged under a single factor. The eigenvalue of the single factor obtained was 2.928 , and the percentage of variance explained was $73.197 \%$. The internal consistency coefficient of the scale was 0.88 .

\section{Job Performance Scale}

Having been employed by Sigler and Pearson $(C ̧ o ̈ l, 2008)$ in their studies, the job performance scale consists of four items. The response categories of the items in this scale are graded on a 5-point scale (1:Strongly Disagree, 5:Strongly Agree). The scale was adapted by Çöl (2008) for use in Turkish. The internal consistency of the scale was 0.828 , and the factor loadings were found to be between 0.781 and 0.847 .

\section{U-MICS}

Developed by (Crocetti et al. 2008), The U-MICS was used in this study to assess identity process. The scale was adapted by (Morsunbul et al 2014) for use in Turkish. The items in the scale are rated on a 5-point Likert scale (1:Completely untrue, 5:Completely true). The scale consists of three dimensions: commitment-5 items), in-depth exploration-5 items) and reconsideration of commitment- 3 items. The internal consistency coefficient of the scale was 0.87 for commitment, 0.80 for in-depth exploration, and 0.79 for reconsideration of commitment.

\section{Organizational Identification Scale}

Developed by (Mael \& Ashforth, 1992), the organizational identification scale consists of six items that are rated on a 5-point Likert scale (1:Strongly Disagree, 5:Strongly Agree). The scale was adapted by (Tüzün, 2006) for use in Turkish. In the study of (Tüzün, 2006), the KMO value performed before the factor analysis was .764. The Bartlett test yielded $\chi 2(15)=891.69, \mathrm{p}<.001$. The single factor with an eigenvalue of 2.89 explained $48.13 \%$ of the total variability. The internal consistency coefficient of the scale was calculated as $\alpha=.78$ (Mael \& Ashforth, 1992; Tüzün, 2006).

\section{Data Analysis}

The correlation coefficients between the organizational trust, job performance, identity and organizational identification variables were calculated. SEM's were established in order to analyze the effects of organizational identification and identity on organizational trust in the first stage of the study and to examine the effects of organizational identification, identity and organizational trust on job performance in the second stage. A path analysis was performed for the model established with SEM to determine the most appropriate model describing the existing relations. In this study, each SEM test was carried out in two stages. Accordingly, a confirmatory factor analysis with all latent variables in the model was performed first. In addition, an observed variable was created by taking the total score of each sub-factor of the identity implicit variable, and the latent variable was defined in this way. The appropriateness of the SEM models was assessed by examining the goodness of fit indexes.

\section{Results}

The results obtained from the personal information form administered to the health professionals participating in the study are shown in Table 2. 
S. Tekingündüz - E. Karabel - A. Zekioğlu - S. Ö. Sünbül 12/2 (2020) 1192-1206

Table 2. Demographic information about the health professionals

\begin{tabular}{|c|c|c|c|}
\hline & & Frequency & Percent \\
\hline \multirow{2}{*}{ Gender } & Female & 244 & 61,5 \\
\hline & Male & 153 & 38,5 \\
\hline \multirow{2}{*}{ Marital Status } & Married & 260 & 65,5 \\
\hline & Single & 137 & 34,5 \\
\hline \multirow{3}{*}{ Educational Level } & High school & 62 & 15,6 \\
\hline & Associate degree & 150 & 37,8 \\
\hline & \begin{tabular}{|l|} 
Graduate / Post \\
Graduate
\end{tabular} & 185 & 46,6 \\
\hline Age (Years) & \multicolumn{3}{|c|}{$32,69 \pm 7,04$} \\
\hline Length of time in current job (Years) & \multicolumn{3}{|c|}{$11,26 \pm 7,2$} \\
\hline Length of time in current organization (Years) & \multicolumn{3}{|c|}{$6,50 \pm 5,3$} \\
\hline
\end{tabular}

The reliability and factor analysis results of the scales used in the study are shown in Table 3.

Table 3. Reliability and Factor Analysis Results of the Variables

\begin{tabular}{|c|c|c|c|c|c|}
\hline & $\begin{array}{l}\text { Factor } \\
\text { loads }\end{array}$ & $\begin{array}{c}\text { KMO } \\
\text { (Barttlett) }\end{array}$ & $\begin{array}{l}\text { Percentage } \\
\text { of } \\
\text { explained } \\
\text { variance } \\
(\%)\end{array}$ & Eigenvalues & Cronbach's alpha $(\alpha)$ \\
\hline \multicolumn{6}{|c|}{ Organizational Trust } \\
\hline $\mathrm{T} 1$ & 905 & \multirow{4}{*}{$\begin{array}{l}(804,87, \\
\mathrm{p}=0.000)\end{array}$} & \multirow{4}{*}{66,561} & \multirow{4}{*}{2.662} & \multirow{4}{*}{.829} \\
\hline $\mathrm{T} 2$ & ,900 & & & & \\
\hline $\mathrm{T} 3$ & ,752 & & & & \\
\hline $\mathrm{T} 4$ & 684 & & & & \\
\hline \multicolumn{5}{|c|}{ Job Performance } & \multirow{5}{*}{.765} \\
\hline P1 & 813 & \multirow{4}{*}{$\begin{array}{l}(389,515 \\
p=0,000)\end{array}$} & \multirow{4}{*}{58,829} & \multirow{4}{*}{2.363} & \\
\hline $\mathrm{P} 2$ & ,777 & & & & \\
\hline P3 & ,763 & & & & \\
\hline $\mathrm{P} 4$ & ,712 & & & & \\
\hline \multicolumn{5}{|c|}{ Organizational Identification } & \\
\hline $\mathrm{I} 1$ & ,733 & \multirow{6}{*}{$\begin{array}{c}0.829 \\
1002,027 \\
p=0.000)\end{array}$} & \multirow{6}{*}{57,455} & \multirow{6}{*}{3.447} & \multirow{6}{*}{.846} \\
\hline $\mathrm{I} 2$ & 681 & & & & \\
\hline $\mathrm{I} 3$ & ,578 & & & & \\
\hline $\mathrm{I} 4$ &, 522 & & & & \\
\hline $\mathrm{I} 5$ & 469 & & & & \\
\hline $\mathrm{I} 6$ & 465 & & & & \\
\hline
\end{tabular}


Table 4. Reliability and Factor Analysis Results of the U-MICS

\begin{tabular}{|c|c|c|c|c|c|c|}
\hline & $\begin{array}{c}\text { I } \\
\text { (Commitme } \\
\text { nt) }\end{array}$ & $\begin{array}{c}\text { II } \\
\text { (In-depth } \\
\text { exploration } \\
\text { ) }\end{array}$ & $\begin{array}{c}\text { III } \\
\text { (Reconsideration } \\
\text { of commitment) }\end{array}$ & $\begin{array}{c}\text { Percentage } \\
\text { of } \\
\text { explained } \\
\text { variance } \\
(\%)\end{array}$ & $\begin{array}{l}\text { Eigenvalu } \\
\text { es }\end{array}$ & $\begin{array}{c}\text { Cronbach's alpha } \\
(\alpha)\end{array}$ \\
\hline $\mathrm{C} 1$ & .879 & & & \multirow{5}{*}{40.508} & \multirow{5}{*}{5.266} & \multirow{5}{*}{.919} \\
\hline $\mathrm{C} 2$ & .865 & & & & & \\
\hline $\mathrm{C} 3$ & .853 & & & & & \\
\hline $\mathrm{C} 4$ & .820 & & & & & \\
\hline $\mathrm{C} 5$ & .719 & & & & & \\
\hline IN1 & & .793 & & \multirow{5}{*}{18.911} & \multirow{5}{*}{2.458} & \multirow{5}{*}{.776} \\
\hline IN2 & & .763 & & & & \\
\hline IN3 & & .686 & & & & \\
\hline IN4 & & .670 & & & & \\
\hline IN5 & & .549 & & & & \\
\hline $\mathrm{RC} 1$ & & & .895 & \multirow{3}{*}{9.967} & \multirow{3}{*}{1.296} & \multirow{3}{*}{.890} \\
\hline $\mathrm{RC} 2$ & & & .894 & & & \\
\hline RC3 & & & .879 & & & \\
\hline
\end{tabular}

The factor analysis results showed that four items in the organizational trust scale, four items in the job performance scale and six items in the organizational identification scale converged on a single dimension. In addition to this, five items in the commitment dimension in the Identity Commitments Scale, five items in the in-depth exploration dimension, and three items in the reconsideration of commitment converged on a single factor. The reliability coefficients of all the scales were found to be high in the analyses (Table 3, Table 4).

The correlation coefficients calculated between the organizational identification, identity, organizational trust and job performance variables are shown in Table 5.

Table 5. Correlation Coefficients Calculated Between the Variables

\begin{tabular}{|l|c|c|c|c|c|c|c|}
\hline & Mean \pm SD & 1 & 2 & 3 & 4 & 5 & 6 \\
\hline 1. Organizational trust & $2,90 \pm, 94$ & 1 & & & & & \\
\hline 2. Job performance & $4,05 \pm, 71$ &, $176^{*}$ & 1 & & & & \\
\hline $\begin{array}{l}\text { 3. Organizational } \\
\text { Identification }\end{array}$ & $3,61 \pm, 88$ &, $512^{*}$ &, $267^{*}$ & 1 & & & \\
\hline 4. Commitment & $3,84 \pm, 84$ &, $369^{*}$ &, $244^{*}$ &, $271^{*}$ & 1 & & \\
\hline 5. In-depth exploration & $3,68 \pm, 71$ &, $198^{*}$ &, $316^{*}$ &, $388^{*}$ &, $495^{*}$ & 1 & \\
\hline $\begin{array}{l}\text { 6. Reconsideration of } \\
\text { commitment }\end{array}$ & $2,76 \pm 1,18$ &,$- 149^{*}$ &,- 089 &,$- 130^{*}$ &,$- 343^{*}$ & $-0,037$ & 1 \\
\hline 7. Identity (U-MICS) & $3,42 \pm, 52$ &, $176^{*}$ &, $208^{*}$ &, $225^{*}$ &, $505^{*}$ &, $693^{*}$ &, $550^{*}$ \\
\hline
\end{tabular}

*. Correlation is significant at the 0.01 level (2-tailed).

As can be seen in Table 5, positive significant relationships were found between the organizational trust variable and the job performance, organizational identification and identity variables. On the other hand, a negative significant relationship was determined between organizational trust and the commitment dimension in the Identity Commitments Scale. There were also positive significant relationships with job performance and organizational identification, identity and two dimensions of the Identity Commitments Scale (i.e., Commitment and In-depth exploration). 


\section{Measurement Model 1}

The measurement model, which was created as a result of the confirmatory factor analysis to examine the relationship between the latent variables (i.e., organizational identification, identity, and organizational trust), is shown in Figure 1. Also, Figure 2 shows the standardized path coefficients of the measurement model, the $\mathrm{t}$-values related to whether these coefficients were significant or not and the goodness of fit indices indicating whether the model could be accepted as a whole.

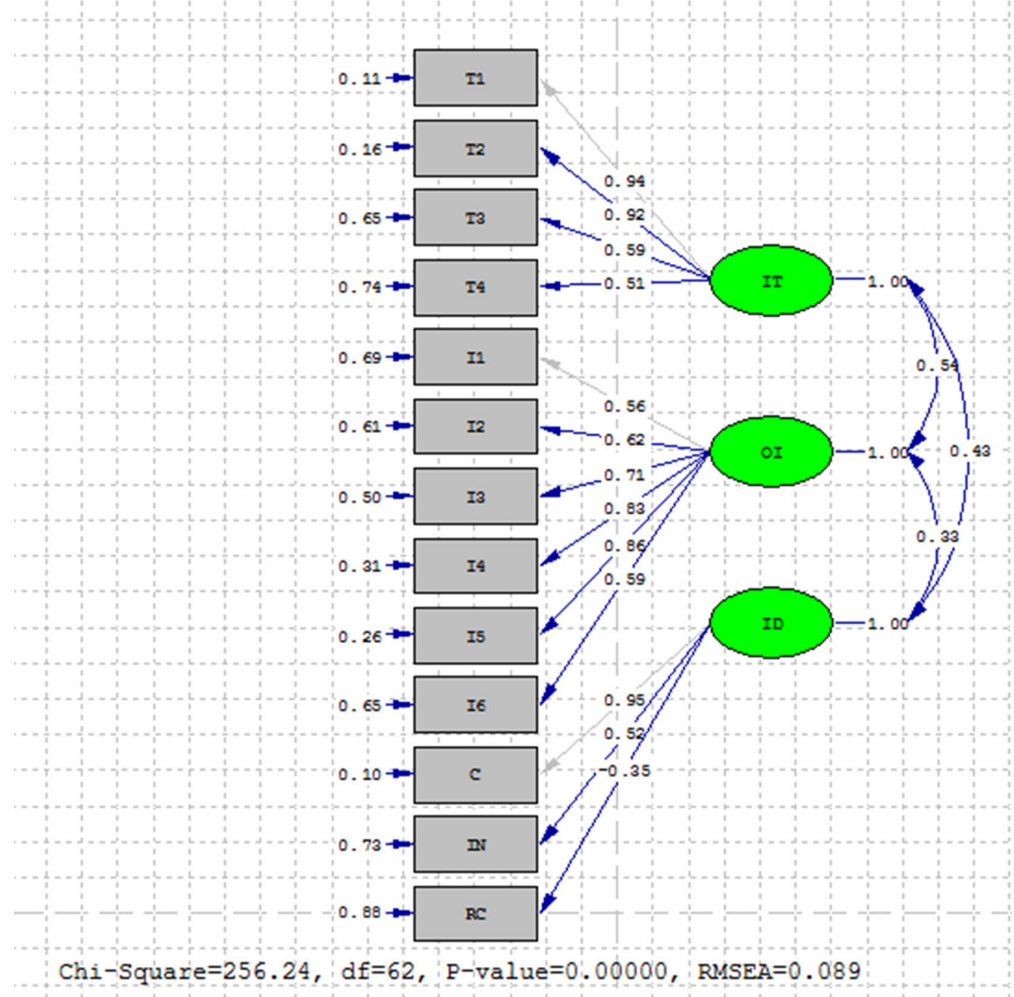

Figure 1: Standardized Path Coefficients of Measurement Model 1 (IT:Organizational Trust, OI:

Organizational Identification, ID: Identity)

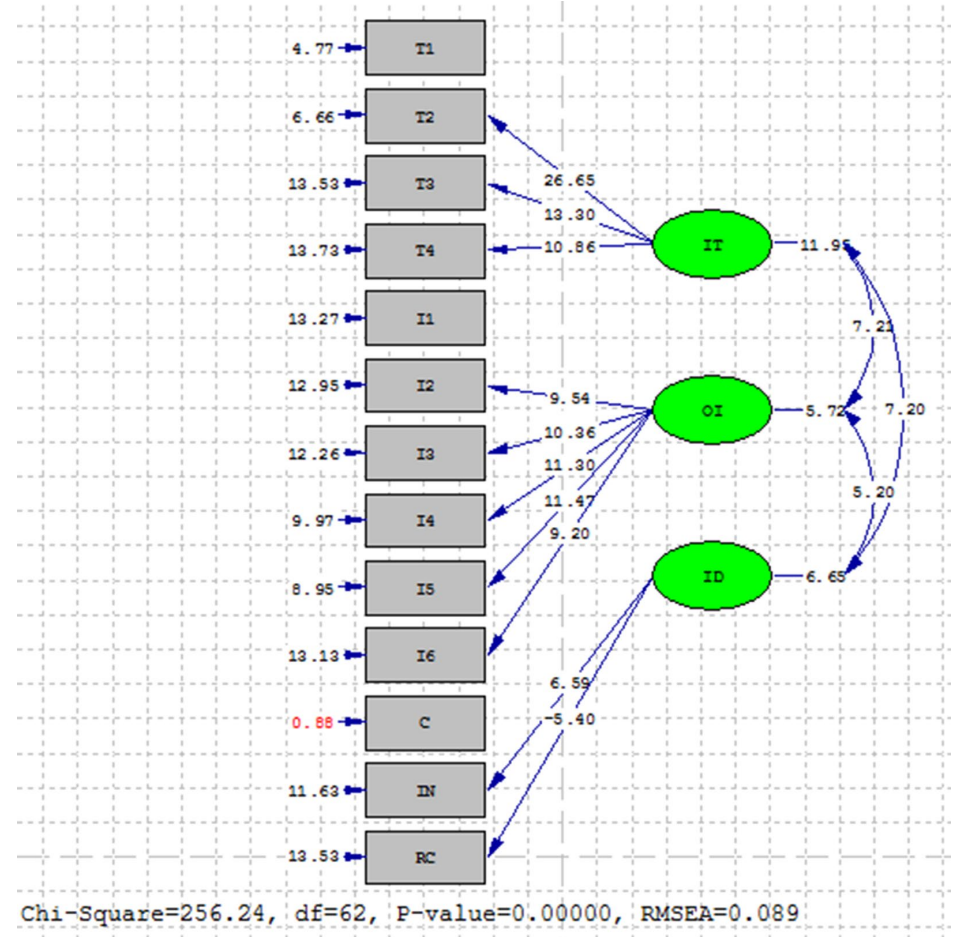

Figure 2: $t$-values for Measurement Model 1 
The relationships between all the observed variables in the measurement model and their corresponding latent variables and the relationships of the latent variables with each other were significant (Figure 1). Figure 2 shows t-values in relation to whether or not the path coefficients between the variables in the above path diagram were significant. Accordingly, all the $t$-values in the measurement model were statistically significant.

According to the goodness of fit indixes of the measurement model, the Goodness of Fit Index (GFI) score was .91, the Adjusted Goodness of Fit Index (AGFI) was .87, the Comparative Fit Index (CFI) score was .91, the Normed Fit Index (NFI) was .89, and the Root Mean Square Error of Approximation (RMSEA) score was 0.089. We could suggest that the measurement model was acceptable because the goodness of fit scores showed a good fit that was close to the standards.

\section{SEM 1}

As a part of the process in which the SEM was tested, the structural model created was presented in Figure 3, and the standardized path coefficients of the structural model, the $t$-values related to whether these coefficients were significant or not and the goodness of fit indices indicating whether the model could be accepted as a whole were also shown.

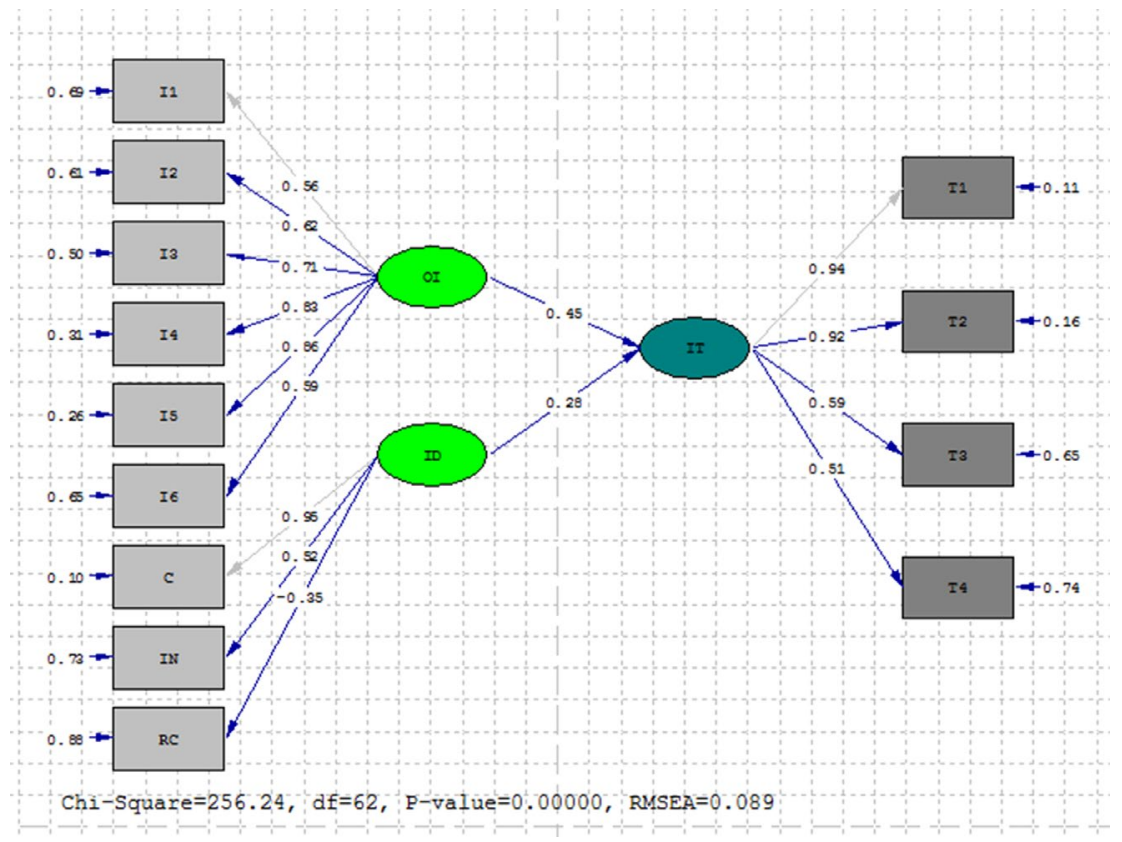

Figure 3: Standardized Path Coefficients of the Structural Model

The relationships between all the observed variables in the SEM and their corresponding latent variables and the relationships of the latent variables with each other were significant (Figure 3). The organizational identification and organizational trust variables had moderate and large relationships with their observed variables. Also, the identity latent variable had moderate and large relationships with the other observed variables, except for the third observed variable. Finally, the standardized path coefficient between the organizational trust variable and the latent variable of organizational identification was higher than the identity latent variable. 


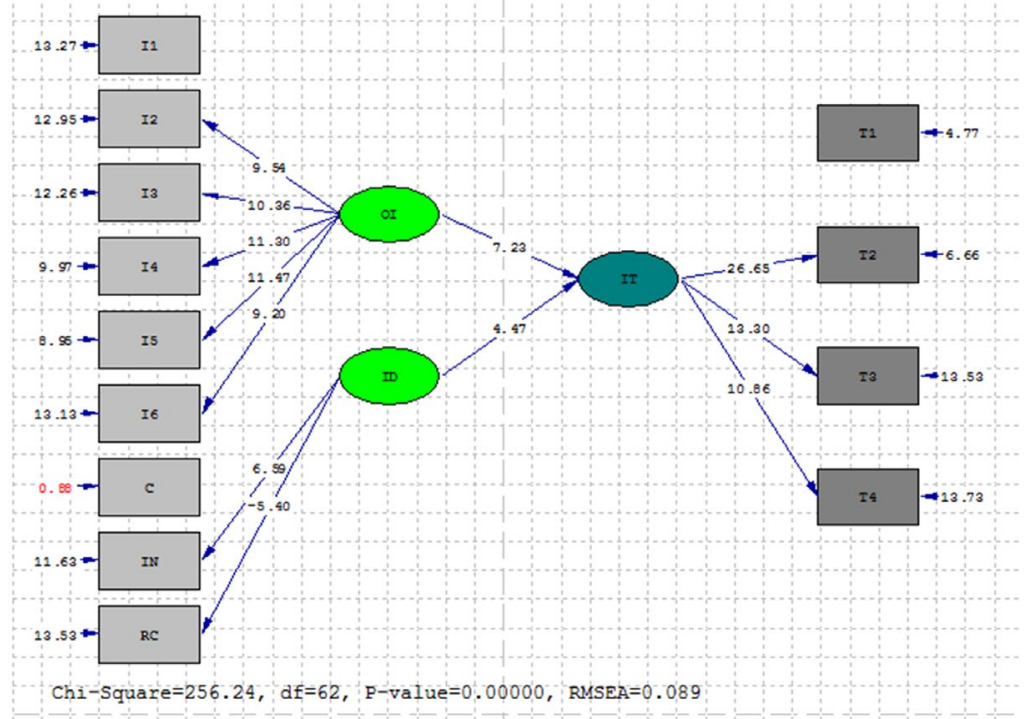

Figure 4: t-values of the Structural Model

All t-values in the structural model were statistically significant. According to the goodness of fit indices of the model, the GFI score was .91, the AGFI was .87, the CFI score was .91, the NFI was .89, and the RMSEA score was 0.089 . We could suggest that the SEM was acceptable because the goodness of fit scores showed a good fit that was close to the standards (Figure 4).

\section{Measurement Model 2}

The measurement model, which was created as a result of the confirmatory factor analysis to examine the relationship between the latent variables is shown in Figure 5. Also, Figure 6 shows the standardized path coefficients of the measurement model, the $t$-values related to whether these coefficients were significant or not and the model goodness of fit indices indicating whether the model could be accepted as a whole.

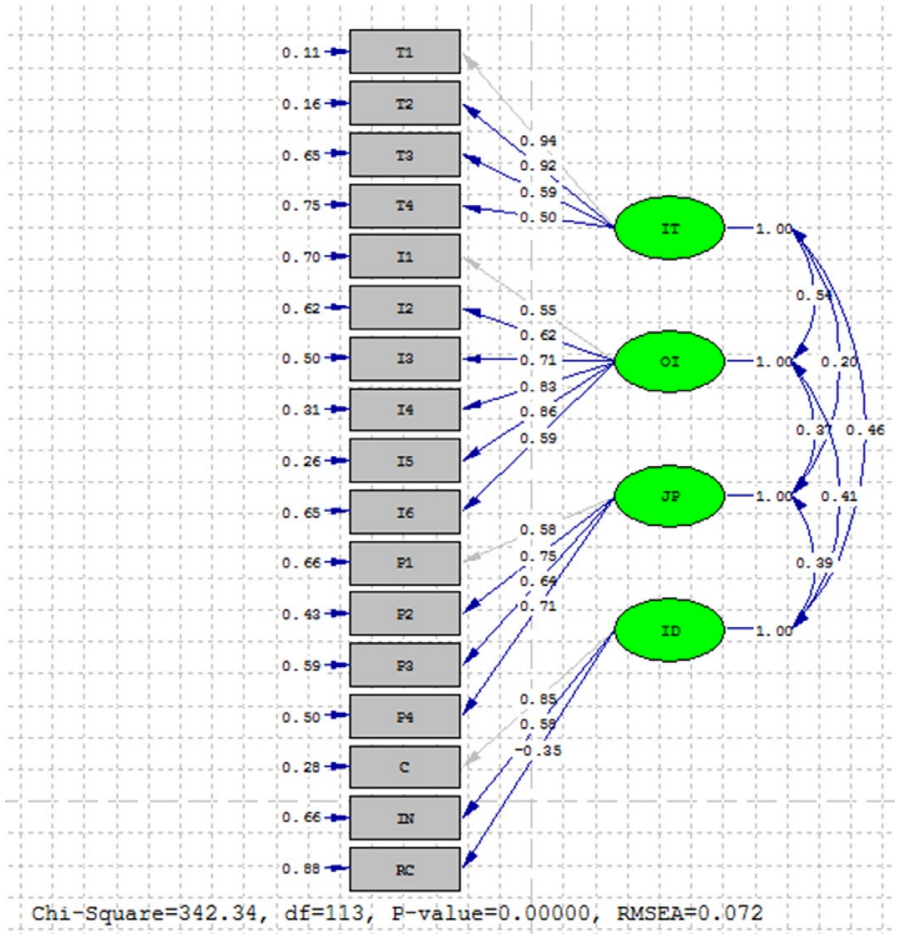

Figure 5: Standardized Path Coefficients of Measurement Model 2 (IT:Organizational Trust, OI: Organizational Identification, JP: Job Performance, ID: Identity) 


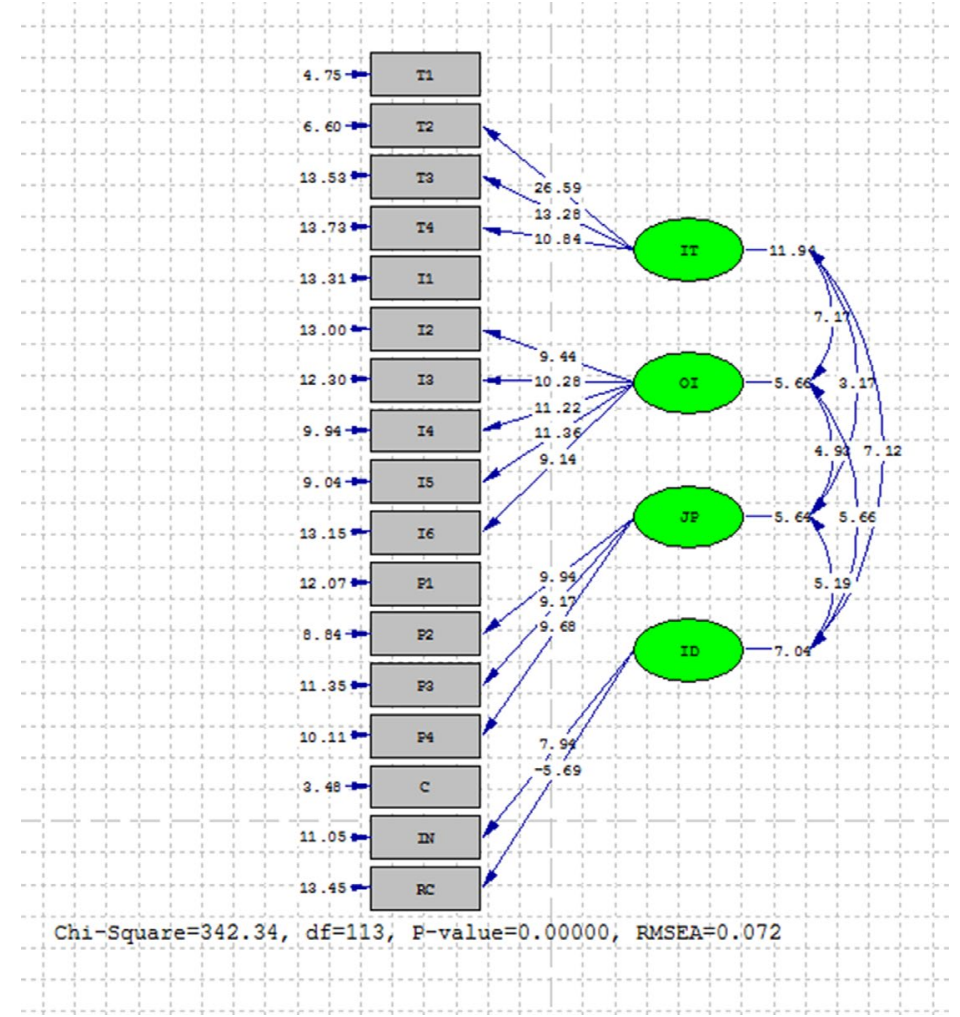

Figure 6: t-values for Measurement Model 2

The relationships between all the observed variables in the measurement model and their corresponding latent variable and the relationships of the latent variables with each other were significant (Figure 5). Figure 6 shows $\mathrm{t}$-values for measurement model 2. Accordingly, all the $\mathrm{t}$-values in the measurement model were statistically significant. According to the goodness of fit indices of the measurement model, the GFI score was .91, the AGFI was .88, the CFI score was .91, the NFI was .88, and the RMSEA score was 0.072 . We could suggest that the measurement model was acceptable because the goodness of fit scores indicated a good fit that was close to the standards.

\section{SEM 2}

As a part of the process in which SEM 2 was tested, the structural model created was presented in Figure 7. Also, the standardized path coefficients of the structural model, the $t$-values related to whether these coefficients were significant or not and the model goodness of fit indices indicating whether the model could be accepted as a whole were shown in Figure 8. When the model was examined, the organizational trust variable was removed from the model and the model was re-established and examined because the coefficient indicating the effect of the organizational trust variable on job performance was not significant. 
S. Tekingündüz - E. Karabel - A. Zekioğlu - S. Ö. Sünbül 12/2 (2020) 1192-1206

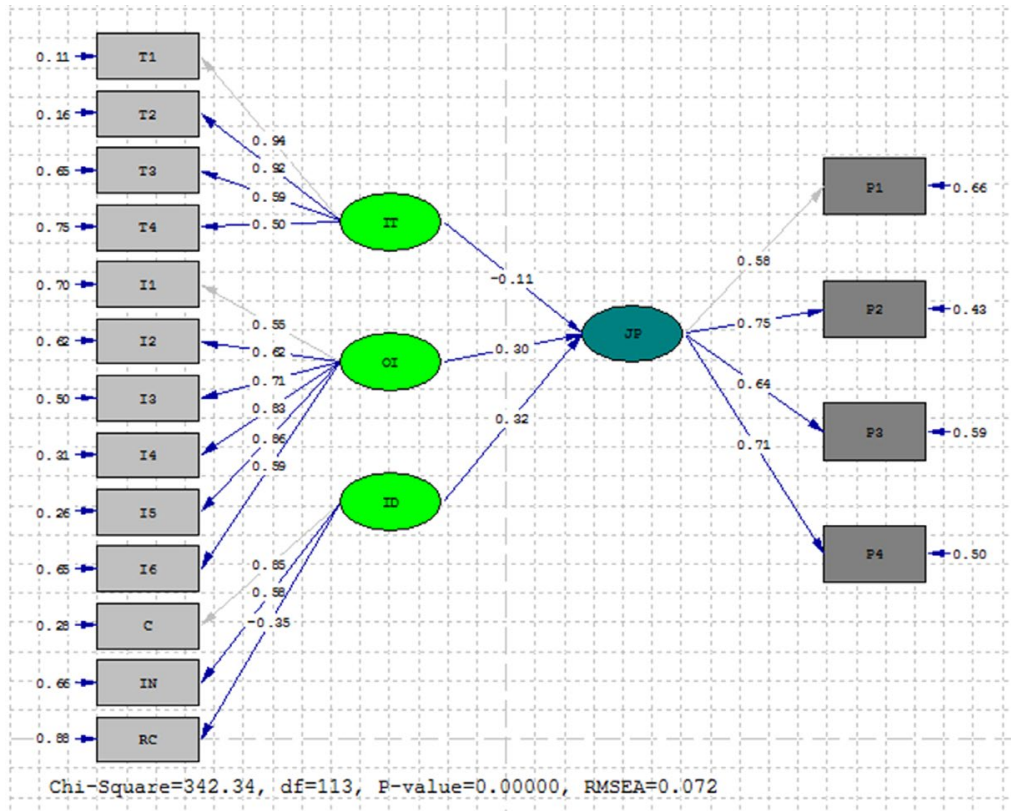

Figure 7: Standardized Path Coefficients of the Structural Model

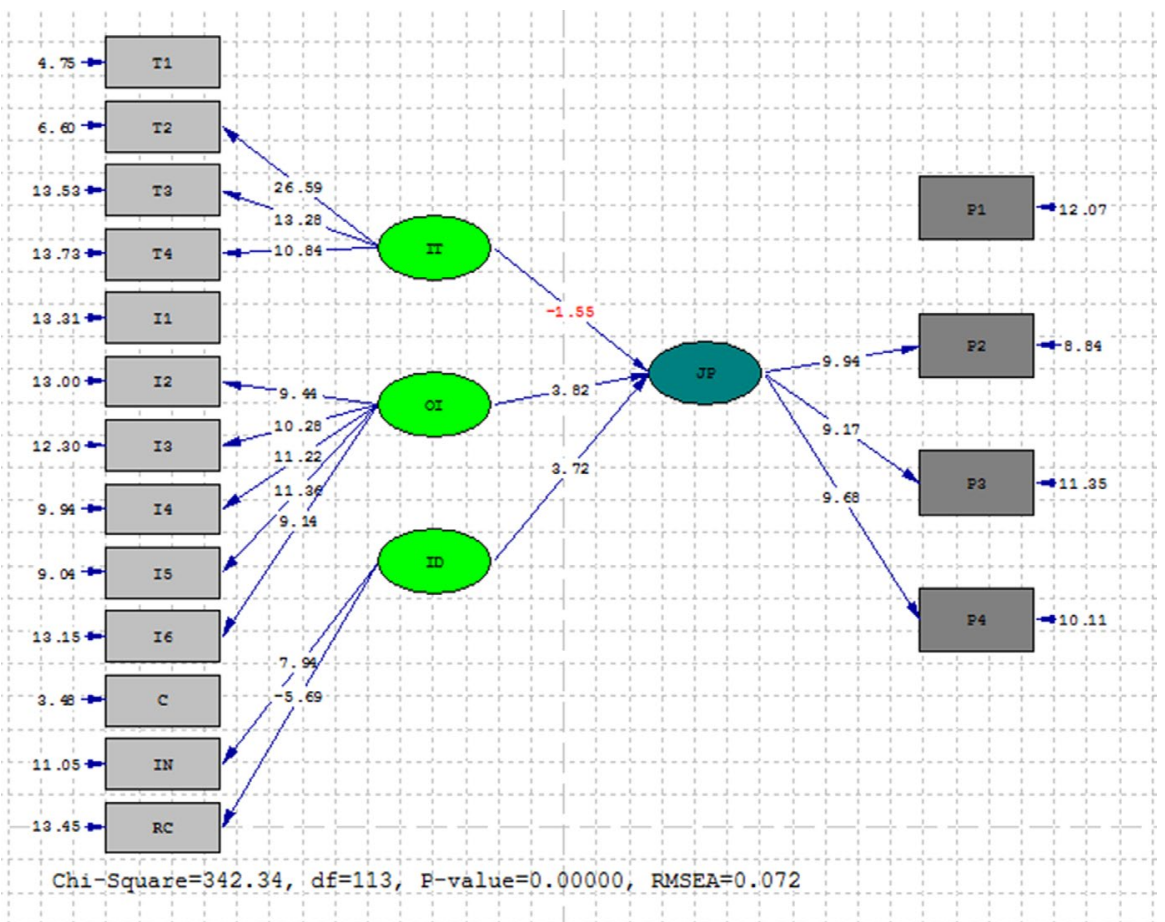

Figure 8: t-values of the Structural Model

The standardized path coefficients and t-values included in the model created to illustrate organizational identification, identity and job performance were presented in the following figures. The latent variables of organizational identification, identity and job performance had significant relationships with all their observed variables (Figure 9). The standardized path coefficient between the job performance variable and the identity latent variable was higher than the organizational identification latent variable. 
S. Tekingündüz - E. Karabel - A. Zekioğlu - S. Ö. Sünbül 12/2 (2020) 1192-1206

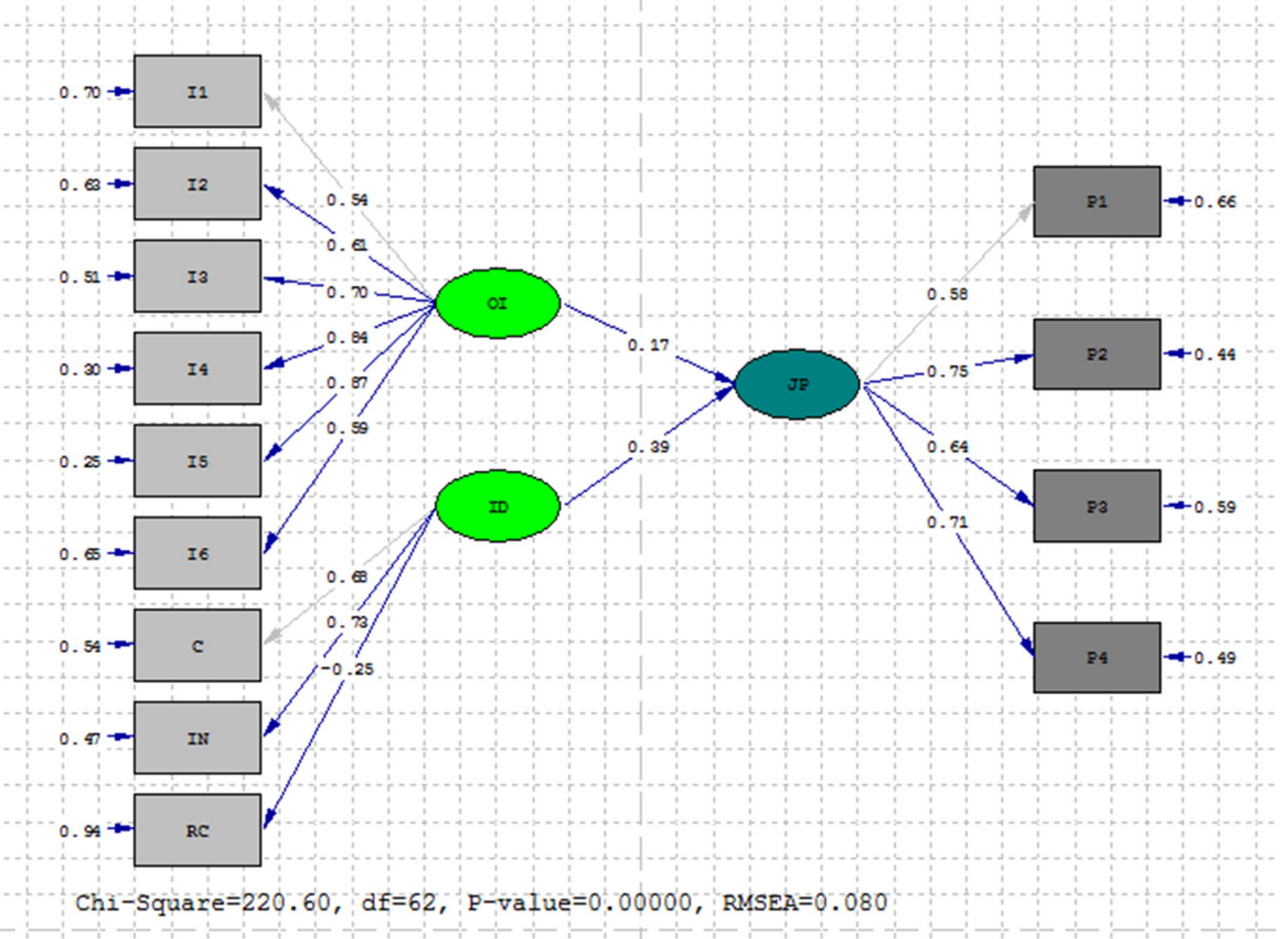

Figure 9: Standardized Path Coefficients of the Structural Model

Figure 10 shows $\mathrm{t}$-values for the structural model created. Accordingly, all $\mathrm{t}$-values in the structural model were statistically significant. According to the goodness of fit indices of the model, the GFI score was .92, the AGFI was .88, the CFI score was .91, the NFI was .88, and the RMSEA score was 0.080 . We could suggest that the SEM was acceptable because the goodness of fit scores indicated a good fit that was close to the standards.

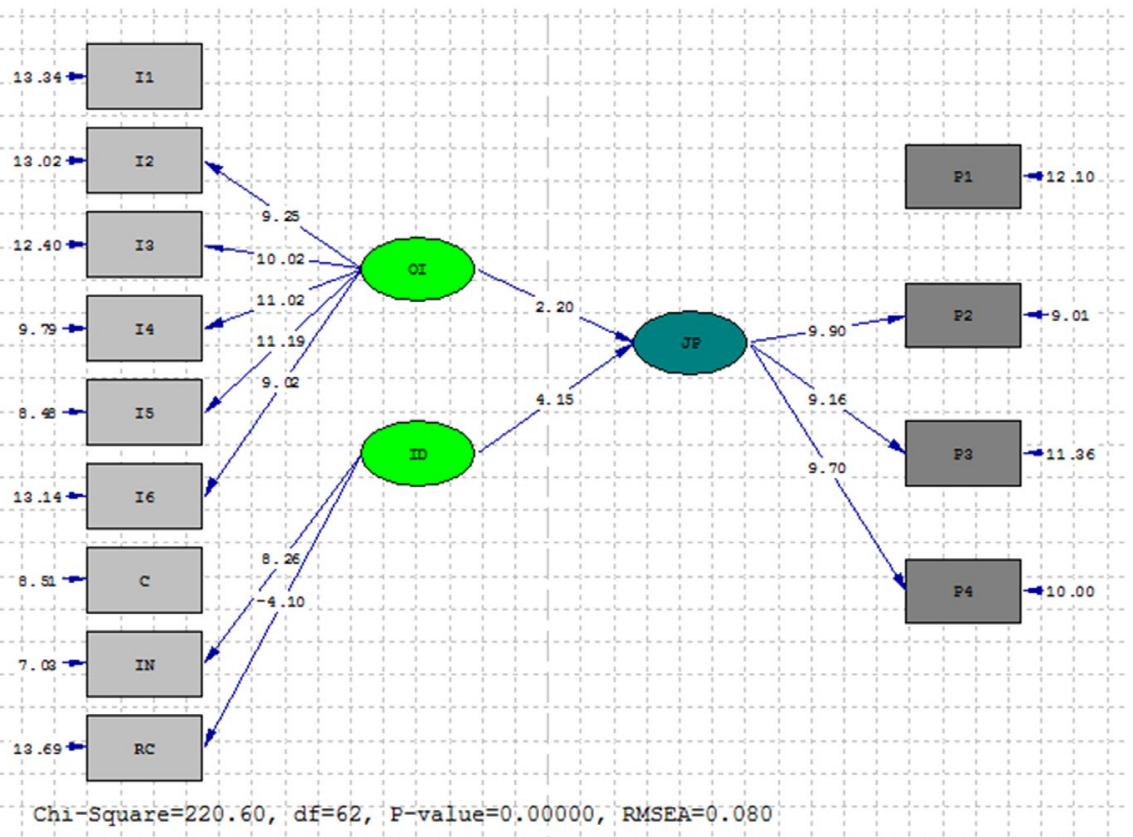

Figure 10: t-values of the Structural Model

\section{Discussion}

In order to maintain the continuity of the organizations and to maintain the competitive advantage, it has become the priority of the human resources departments of organizations to keep competent employees in the organization, to earn their trust, to bring new ones to the organization, and to encourage employees to make more efforts voluntarily. The concept of trust is one of the important structural connections between the employee and the organization. There is always a risk for the one who trusts in organizational trust, in which 


\section{S. Tekingündüz - E. Karabel - A. Zekioğlu - S. Ö. Sünbül 12/2 (2020) 1192-1206}

the one who trusts has positive expectations about the future behavior of the one who is trusted and the one who trusts remains willingly vulnerable to the actions of the one who is trusted (Fulmer \& Gelfand, 2012; Schoorman et al. 2007).

In this study, according to the correlation analysis, positive significant relationships were found between the organizational trust variable and the job performance, organizational identification and identity variables. According to the SEM results, one of the predictors of organizational trust was organizational identification and the other was identity. However, the standardized path coefficient between the organizational trust variable and organizational identification latent variable was higher than the identity latent variable. Based on the findings, it can be argued that the health professionals' willingness to defend and support their organizations, having a strong sense of belonging to their organizations, integration of the organizational goals in harmony with their own targets positively affect the level of trust. Nevertheless, thinking about factors such as the content of work, the work environment, workload, career opportunities and so on, employees gradually begin to compare their existing commitment with other possible alternatives by the nature of health services. When their existing commitment is no longer satisfactory, this can also adversely affect employee trust. Our correlation findings also confirm this case. Similarly, recent studies suggest a positive correlation between organizational trust and organizational identification (Campbell \& Im, 2015; Ng, 2015)

(Gregg \& Magilvy, 2001) emphasize the importance of creating a suitable environment for health professionals to continue working in health organizations and allowing employees to think about the meaning and value of each experience. This situation may also affect trust and performance positively by creating a ground for identification. Skills, ability, knowledge and trust in profession allow nurses to develop a stronger sense of professional identity (Sharbaugh, 2009). Nurses now see themselves as more autonomous and active professionals at the heart of patient care (Cowin et al. 2013).

In this study, according to the correlation analysis, positive significant relationships were observed between job performance and the organizational identification and identity variables. According to the SEM results, it was determined that the identity and organizational identification variables were important determinants of job performance. The standardized path coefficient between the work performance variable and the identity latent variable was higher than the organizational identification latent variable. A strong professional identity is important for an occupation in achieving professional status and providing quality services to the society (Sabancıogulları \& Doğan, 2012). It can be argued that strong professional identities play an important role in raising both trust and performance, given that professional identity directly affects professional practice. In this respect, insufficient development or inability to develop professional identity can lead to serious problems in health care.

When employees feel that their organization is a part of them, this could increase performance. Therefore, there seems to be an important relationship the employee adopting the values, norms and objectives of the organization and increasing his or her performance. (Callea et al. 2016) state that employees who harmonize the objectives of the organization with their own goals will better perform their work with the contribution of organizational identification. Studies show that organizational identification can result in performance increase because the employee who has strong identification with his or her organization would make more efforts, offer the best contribution to the social system, cooperate and have decreased turnover intention, and employee turnover rate would decrease. Also, a strong sense of belonging would increase performance (Carmeli et al. 2007) . According to (Tüzün \& Çağlar, 2008) while individuals identify with organizations to eliminate their need for belonging and reduce uncertainty, organizations want to strengthen their identification because it has a positive impact on their performance. According to et al. 2008), the more an individual is identified with the organization, the more effort he or she is expected to make on behalf of the organization.

There are several studies in the literature supporting our findings about job performance and organizational identification (Carmeli et al., 2007; Knippenberg, 2000; Ng, 2015; Walumbwa et al., 2008). (Knippenberg, 2000) and (Walumbwa et al., 2008) emphasize the importance of motivation in the relationship between identification and performance. According to the authors, identification would have a positive impact on performance by the extent to which it results in job motivation. 


\section{Conclusions}

In this study, it was determined that organizational identification and professional identity significantly affected organizational trust. As a result, it can be argued that the health professionals' willingness to advocate and support their organization and their possession of a strong sense of belonging to their organization positively affected their trust level. Also, their professional identity had a positive impact on the employees' trust.

It was also found that organizational identification and job identity had a significant effect on job performance. The fact that organizational trust had no direct effect on job performance was an important finding in the study.

\section{Limitations}

There are some limitations in our study. A potential limitation of our study is the use of cross-sectional data. Therefore, causality was not revealed. Secondly, the study was conducted in public hospitals in only one city in Turkey. Thus, the study results can be generalized to neither other public hospitals in Turkey nor public hospitals in other countries. Thirdly, the study was conducted solely with those who participated voluntarily. Finally, only non-physician health professionals were included in the study. Despite these limitations, we believe that the current study achieved its main objectives.

\section{References}

Adams, G. R., \& Marshall, S. K. (1996). A developmental social psychology of identity: Understanding the person-in-context. Journal of adolescence, 19(5), 429-442.

Altuntas, S., \& Baykal, U. (2010). Relationship between nurses' organizational trust levels and their organizational citizenship behaviors. Journal of nursing scholarship, 42(2), 186-194.

Aryee, S., Budhwar, P. S., \& Chen, Z. X. (2002). Trust as a mediator of the relationship between organizational justice and work outcomes: Test of a social exchange model. Journal of Organizational Behavior: The International Journal of Industrial, Occupational Organizational Psychology Behavior, 23(3), 267-285.

Ashforth, B. E., Harrison, S. H., \& Corley, K. G. (2008). Identification in organizations: An examination of four fundamental questions. Journal of management, 34(3), 325-374.

Ashforth, B. E., \& Mael, F. (1989). Social identity theory and the organization. J Academy of management review, 14(1), 20-39.

Bakker, A. B., \& Schaufeli, W. B. (2008). Positive organizational behavior: Engaged employees in flourishing organizations. The International Journal of Industrial, Occupational Organizational Psychology and Behavior, 29(2), 147-154.

Bitmiş, M. G., \& Ergeneli, A. (2013). The role of psychological capital and trust in individual performance and job satisfaction relationship: A test of multiple mediation model. Procedia-Social and Behavioral Sciences, 99, 173-179.

Callea, A., Urbini, F., \& Chirumbolo, A. (2016). The mediating role of organizational identification in the relationship between qualitative job insecurity, OCB and job performance. Journal of Management Development, 35(6), 735-746.

Campbell, J. W., \& Im, T. (2015). Identification and trust in public organizations: A communicative approach. Public Management Review, 17(8), 1065-1084.

Carmeli, A., Gilat, G., \& Waldman, D. A. (2007). The role of perceived organizational performance in organizational identification, adjustment and job performance. Journal of Management Studies, 44(6), 972-992.

Ceylan, A., Ulutürk, Y. H. (2006). Rol belirsizliği, rol çatışması, iş tatmini ve performans arasındaki ilişkiler. Doğuş Üniversitesi Dergisi, No:7, 48-58. 
S. Tekingündüz - E. Karabel - A. Zekioğlu - S. Ö. Sünbül 12/2 (2020) 1192-1206

Chughtai, A. A., \& Buckley, F. (2011). Work engagement: Antecedents, the mediating role of learning goal orientation and job performance. Career Development International, 16(7), 684-705.

Cowin, L. S., Johnson, M., Wilson, I., \& Borgese, K. (2013). The psychometric properties of five Professional Identity measures in a sample of nursing students. Nurse Education Today, 33(6), 608-613.

Crocetti, E., Rubini, M., \& Meeus, W. (2008). Capturing the dynamics of identity formation in various ethnic groups: Development and validation of a three-dimensional model. Journal of adolescence, 31(2), 207222.

Crocetti, E., Schwartz, S. J., Fermani, A., \& Meeus, W. J. E. J. o. P. A. (2010). The Utrecht-management of identity commitments scale (U-MICS). European Journal of Psychological Assessment, 26(3), 172-186.

Cummings, L. L., \& Bromiley, P. (1996). The organizational trust inventory (OTI) (Vol. 302): SAGE.

Çöl, G. (2008). Algılanan güçlendirmenin işgören performansı üzerine etkileri. Doğuş Üniversitesi Dergisi, 9(1), 35-46.

Dirks, K.T. , Ferrin, D. L. (2002). Trust in leadership meta-analysis. Journal of Applied Psychology, 87(4), 611-628.

Fulmer, C. A., \& Gelfand, M. (2012). At what level (and in whom) we trust: Trust across multiple organizational levels. Journal of management, 38(4), 1167-1230.

Gül, H., Oktay, E., Gokce, H. (2008). İş tatmini, stres, örgütsel bağlllık, işten ayrılma niyeti ve performans arasındaki ilişkiler: Sağlık sektöründe bir uygulama. Akademik Bakış, Sayı 20, 1-11.

Gregg, M. F., \& Magilvy, J. K. (2001). Professional identity of Japanese nurses: bonding into nursing. Nursing Health Sciences, 3(1), 47-55.

Iaffaldano, M.T., Muchinskyi P. M. (1985). Job satisfaction and performance: a meta-analysis, Psychological Bulletin, 97, 251-273.

Kanefuji, A., \& Nakatani, H. (2017). Structure of professional identity of public health nurses working for governmental agencies. Health, 9(13), 1776-1786.

Karatepe, O. M., \& Aga, M. (2016). The effects of organization mission fulfillment and perceived organizational support on job performance: The mediating role of work engagement. International Journal of Bank Marketing, 34(3), 368-387.

Knippenberg, V. (2000). Work motivation and performance: A social identity perspective. Applied psychology, 49(3), 357-371.

Mael, F., \& Ashforth, B. E. (1992). Alumni and their alma mater: A partial test of the reformulated model of organizational identification. Journal of organizational Behavior, 13(2), 103-123.

Mangles, P. (2015). Out of sight out of mind a multilevel model of job satisfaction, organizational trust, perceived isolation, professional deviance and deviant workplace behaviors in remote locations. Trident University International, $\mathrm{PhD}$. Thesis.

Morsunbul, U., Crocetti, E., Cok, F., \& Meeus, W. (2014). Brief report: The Utrecht-Management of Identity Commitments Scale (U-MICS): Gender and age measurement invariance and convergent validity of the Turkish version. Journal of Adolescence, 37(6), 799-805.

$\mathrm{Ng}$, T. W. (2015). The incremental validity of organizational commitment, organizational trust, and organizational identification. Journal of Vocational Behavior, 88, 154-163.

Polat, M. (2009). Örgütsel özdeşleşmenin öncülleri ve ardılları üzerine bir saha çalı̧ması. (PhD), Uludağ Üniversitesi,

Rodrigues, A. P., \& Carlos M, J. (2010). Market orientation, job satisfaction, commitment and organisational performance: the specific case of local public sector. Transforming Government: People, Process Policy, $4(2), 172-192$.

Sabancıoğulları, S., \& Doğan, S. (2012). Profesyonel kimlik gelişimi ve hemşirelik. Anadolu Hemşirelik ve Sağllk Bilimleri Dergisi, 15(4), 275-282. 
S. Tekingündüz - E. Karabel - A. Zekioğlu - S. Ö. Sünbül 12/2 (2020) 1192-1206

Schoorman, F. D., Mayer, R. C., \& Davis, J. H. (2007). An integrative model of organizational trust: Past, present, and future. Academy of Management Review, 32(2), 344-354.

Sharbaugh, S. M. (2009). Relationships among nurses' professional identity, career satisfaction, occupational commitment, and intent to stay: Widener University School of Nursing.

Tüzün, İ.K. \& Çağlar, İ. (2008). Örgütsel Özdeşleşme Kavrami ve İletişim Etkinliği İlişkisi. Journal of Yasar University, 3(9), 1011-1027.

Tüzün, İ. K. (2006). Örgütsel güven, örgütsel kimlik ve örgütsel özdeşleşme ilişkisi; uygulamah bir çalş̧ma. (PhD), Gazi Üniversitesi,

Velez, P. (2006). Effects of organizational trust. University of San Diego, PhD. Thesis.

Viswesvaran, C., \& Ones, D. S. (2000). Perspectives on models of job performance. International Journal of Selection Assessment, 8(4), 216-226.

Walumbwa, F. O., Avolio, B. J., \& Zhu, W. (2008). How transformational leadership weaves its influence on individual job performance: The role of identification and efficacy beliefs. Personnel psychology, 61(4), 793-825.

Witteman, P. S. (2015). Aspects of organizational culture that impact healthcare professionals trust in the organization: A quantitative study. Capella University, PhD. Thesis.

Yousef, D. A. (2000). Organizational commitment: a mediator of the relationships of leadership behavior with job satisfaction and performance in a Non-Western Country. Journal of Managerial Psychology, 15(1), 624. 